\title{
Pericardial interstitial cell senescence responsible for pericardial structural remodeling in idiopathic and postsurgical constrictive pericarditis
}

\author{
Lin Han, MD, Xin Li, MD, Guanxin Zhang, MD, Zhiyun Xu, MD, Dejun Gong, BD, Fanglin Lu, MD, and \\ Xiaohong Liu, MD
}

\begin{abstract}
Objective: Idiopathic and postsurgical constrictive pericarditis is characterized by pericardial structural remodeling that involves fibrosis, calcification, and inflammation. This study aimed to determine whether cell senescence was responsible for pericardial structural remodeling.

Methods: Pericardial interstitial cells derived from patients with idiopathic or postsurgical pericarditis (pericarditis cells) were harvested. Timing of senescence and differences in telomere length were compared between age- and sex-matched controls (nonpericarditis cells). Pericardial interstitial cells derived from normal pericardia were serially passaged until senescence (senescent cells). Apoptosis, collagen matrix, calcium deposition, chemoattractant properties, gene expression profiles, and paracrine effects of senescent cells were compared with nonsenescent cells of passage 2 (nonsenescent cells).

Results: Pericarditis cells displayed senescent changes, including short telomere length, large flattened cell sizes, positive staining for senescence-associated $\beta$-galactosidase, and limited growth capacity. These senescent cells were resistant to apoptosis, produced more collagen matrix, deposited more calcium, and attracted more monocytes/lymphocytes than the nonsenescent cells. A cluster of genes involved in extracellular matrix deposition (connective tissue growth factor, fibronectin, collagen type I, collagen type III, and tissue inhibitors of metalloproteinase-1), calcium deposition (osteopontin, bone sialoprotein, osteonectin, and matrix Gla protein), and inflammatory cell recruitment (interleukin6 , chemoattractant protein- 1 , and tumor necrosis factor- $\alpha$ ) were upregulated in senescent cells, whereas extracellular matrix-degrading enzyme (metalloproteinase- 1 and metalloproteinase-3) was downregulated. Furthermore, senescent cells had the ability to promote the proliferation, differentiation, and senescence of neighboring cells.
\end{abstract}

Conclusions: These findings suggest that senescent cells have characteristics promoting pericardial structural remodeling, but further work is needed to establish causation. (J Thorac Cardiovasc Surg 2017;154:966-75)

From the Institute of Cardiothoracic Surgery, Changhai Hospital, Second Military Medical University, Shanghai, China.

The present study was supported by grants from the National Natural Science Foundation of China (Grants 81170217 and 81370336 to X.L.) and the National Key Research and Development Program of China (No. 2016YFC1100900 to Z.X.).

Lin Han, MD, Xin Li, MD, and Guanxin Zhang, MD, contributed equally to this article.

Received for publication March 17, 2016; revisions received March 4, 2017; accepted for publication March 20, 2017; available ahead of print April 26, 2017.

Address for reprints: Xiaohong Liu, MD, Institute of Cardiothoracic Surgery, Changhai Hospital, Second Military Medical University, 168, Changhai Rd, Shanghai 200433, China (E-mail: bcg709@163.com).

$0022-5223 / \$ 36.00$

Copyright $($ c 2017 by The American Association for Thoracic Surgery

http://dx.doi.org/10.1016/j.jtcvs.2017.03.115

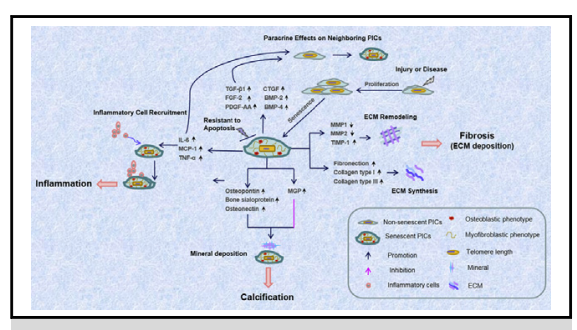

Proposed mechanism of PIC senescence responsible for pericardial structural remodeling.

\section{Central Message}

Cellular senescence may be a potential mechanism contributing to pericardial structural remodeling in IPCP.

\section{Perspective}

Little is known about the pathogenesis of IPCP. We demonstrated that senescent PICs exhibited pronounced functional alterations and selectively regulated fibrocalcific and inflammatory programs. These data suggest that senescent PICs have characteristics promoting pericardial structural remodeling.

See Editorial Commentary page 976.

See Editorial page 953.
Chronic constrictive pericarditis represents a serious hemodynamic syndrome that can lead to heart failure unless surgically treated. Idiopathic and postsurgical constrictive pericarditis (IPCP) is becoming increasingly prevalent,

Scanning this QR code will take you to a supplemental video and tables for the article.

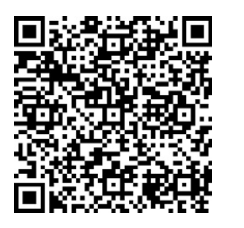




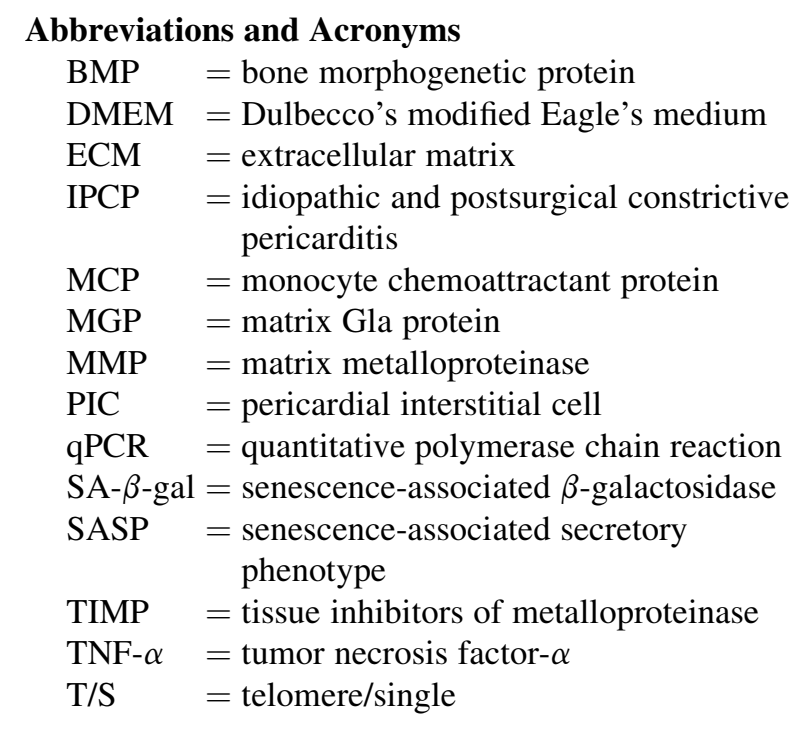

accounting for $33 \%$ to $83 \%$ of the constrictive cases among published studies. ${ }^{1,2}$ IPCP is characterized by pericardial structural remodeling that involves fibrosis, calcification, and various degrees of inflammation. ${ }^{1}$ Theoretically, pericardial structural remodeling, especially fibrocalcification, may result in stiffening of the pericardial walls, thereby contributing to pericardial constriction. Consistent with this concept, the extent of pericardial structural remodeling determined by histology has been shown to correlate with pericardial volume decreases and progressive constriction. ${ }^{3}$ Therefore, a better understanding of the pathogenesis responsible for pericardial structural remodeling is critical for the prevention, early diagnosis, and treatment of IPCP.

Recently, accumulating evidence has suggested that structural cells, such as lung fibroblasts in lung fibrosis ${ }^{4}$ and vascular smooth muscle cells in vascular calcification, ${ }^{5}$ exhibited senescent phenotypes and played important roles in the pathogenesis of remodeling diseases. These senescent cells not only lost their ability to divide but also produced numerous proinflammatory cytokines, chemokines, growth factors, and proteases, which may alter the local tissue environment and contribute to tissue structural remodeling. Pericardial interstitial cells (PICs) are the major structural cells within the pericardia, and we had confirmed in our previous studies that a central event in pericardial injury was the activation of PICs. ${ }^{6,7}$ Therefore, we hypothesized that cellular senescence, as a result of overactivation of PICs, was an important pathologic mechanism of tissue structural remodeling in the progression of IPCP. To test this hypothesis, we compared the rate of senescence in PICs derived from pericardial tissue from patients with and without IPCP. We also compared differences in apoptosis, collagen matrix, calcium deposition, chemoattractant properties, gene expression profiles, and paracrine effects to determine whether PIC senescence was associated with differences in important pericardial structural remodeling variables.

\section{MATERIALS AND METHODS}

The present study conforms to the principles outlined in the Declaration of Helsinki. The study protocol was approved by Changhai Hospital's Ethics Committee, and informed consent was obtained from all patients before the study.

\section{Patients}

Twelve fresh pericardial specimens were acquired from patients with IPCP who underwent pericardiectomy at Changhai Hospital and were used to culture pericarditis PICs. The mean age of the study population was 55 years (range, 23-72 years). The underlying cause of constrictive pericarditis in these patients included idiopathic disease $(9 / 12,75 \%)$ and postcardiac injury syndrome $(3 / 12,25 \%)$. For control, 12 pericardial specimens free of pericarditis were obtained from age- and sex-matched normal subjects at autopsy $(\mathrm{n}=1)$ or during cardiac surgery $(\mathrm{n}=11)$ and were used to culture nonpericarditis PICs. For in vitro functional studies, another 16 pericardial specimens free of pericarditis were used to culture senescent or nonsenescent PICs (passage 2). No patient had histories of idiopathic, autoimmune, or established connective tissue disease. The baseline characteristics of the patients are shown in Tables E1 and E2.

\section{Cell Culture and Replication}

Fresh pericardia were cut into $1-\mathrm{mm}^{3}$ tissue masses, and the explants were cultured in Dulbecco's modified Eagle's medium at $37^{\circ} \mathrm{C}$ (Video 1). After cell outgrowth from the explants, cells were passaged (passage 1), seeded in 12-well plates, and cultured to confluence. The cells were then counted and seeded (passage 2) in 6-well plates. The experiments started at this point, and the cells were serially passaged until senescence. The onset of cell replicative senescence was defined on the basis of cessation of cell division, labeling for senescence-associated $\beta$-galactosidase (SA- $\beta$-gal), and cell morphology criteria such as flat and large cell shape. ${ }^{8}$ PICs of passage 2 were used as control nonsenescent PICs.

\section{In Situ Staining for Cellular Senescence}

Briefly, after being fixed with a $2 \%$ formaldehyde $/ 0.2 \%$ glutaraldehyde solution in phosphate-buffered saline solution, PICs were incubated with SA- $\beta$-gal staining solution for 24 hours at $37^{\circ} \mathrm{C}$. The blue color in the cytoplasm was defined as positive staining, and positive cells were counted by 2 independent blinded investigators. SA- $\beta$-gal activity was evaluated using a semiquantitative system (H-score). The intensity of the blue staining was scored on a scale as 0 (absent), 1 (weak), 2 (moderate), or 3 (strong). The $\mathrm{H}$-score for staining each sample was defined as $\mathrm{H}$-score $=3 \times(\%$ at $3+)+2 \times(\%$ at $2+)+1 \times(\%$ at $1+)+0 \times(\%$ at 0$)$.

\section{Telomere Length Measurement by Quantitative Polymerase Chain Reaction}

Telomere length assessment was performed using a real-time quantitative polymerase chain reaction (qPCR) assay telomere/single (T/S) copy gene values were calculated by $2^{\triangle-\mathrm{Ct}}$, and relative $\mathrm{T} / \mathrm{S}$ values were generated by dividing sample T/S values with the T/S value of a reference cell line DNA., 10

\section{RNA Isolation and Quantitative Polymerase Chain Reaction}

Total RNA was extracted from PICs, reverse-transcribed, and used as a template for the real-time qPCR as described in the Supplementary Methods. 


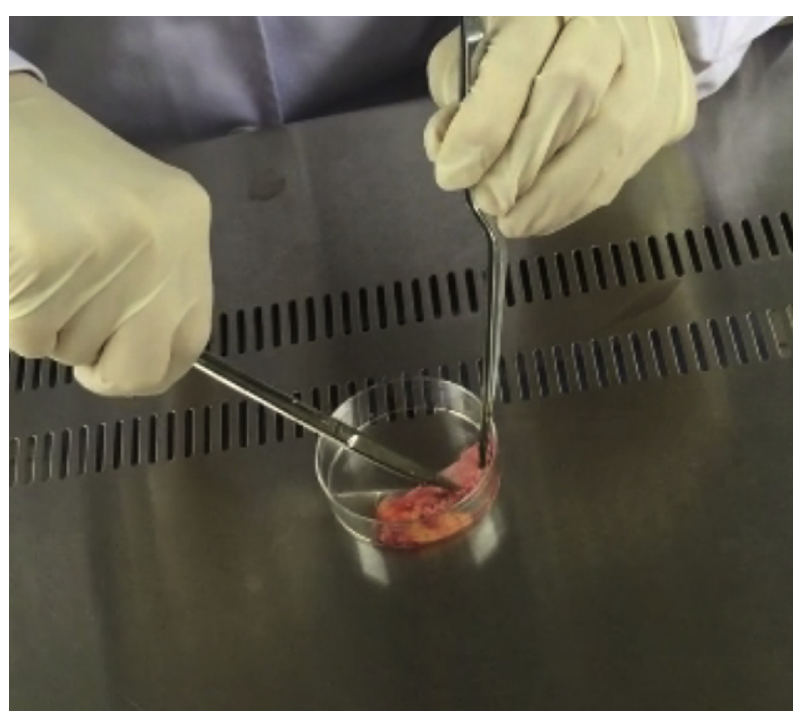

VIDEO 1. Culture procedure of PICs. Briefly, 24-well culture plates were rinsed with Dulbecco's modified Eagle's medium (DMEM) supplemented with $10 \%$ heat-inactivated fetal bovine serum, $100 \mathrm{U} / \mathrm{mL}$ penicillin, and $100 \mu \mathrm{g} / \mathrm{mL}$ streptomycin. Fresh pericardia were washed with DMEM media 3 times and cut into $1-\mathrm{mm}^{3}$ tissue masses. The tissue masses were placed into 24 -well culture plates to adhere for 4 hours at $37^{\circ} \mathrm{C}$ in an atmosphere of $95 \%$ air and $5 \% \mathrm{CO}_{2}$. Subsequently, the explants were cultured in DMEM media. When cells emerged from the explants and formed a monolayer, they were detached from the bottom of the culture dish with trypsin/ ethylenediaminetetraacetic acid to establish subcultures. Video available at: http://www.jtcvsonline.org/article/S0022-5223(17)30634-7/addons.

\section{Cell Proliferation Assay}

Cell proliferation was assessed using the 3-(4,5-dimethylthiazol-2-yl)2,5-diphenyltetrazolium bromide assay. Briefly, cells were seeded at a density of $8 \times 10^{3}$ cells $/ 100 \mu \mathrm{L}$ into 96 -well plates and allowed to adhere. After 24 hours, the original media were replaced with fresh media containing appropriate additives. At the end of the incubation period, cells were treated with 3-(4,5-dimethylthiazol-2-yl)-2,5-diphenyltetrazolium bromide $(5 \mathrm{mg} / \mathrm{mL})$ for 4 hours at $37^{\circ} \mathrm{C}$. The absorbance was measured at $570 \mathrm{~nm}$ by spectrophotometer.

\section{Isolation of CD45-Positive Monocytes/Lymphocytes}

Human peripheral blood mononuclear cells were obtained from healthy volunteers and isolated with Ficoll-Hypaque density gradient centrifugation (Miltenyi Biotec, Bergisch Gladbach, Germany). CD45-positive monocytes/lymphocytes were subsequently sorted by use of magnetic beads according to the manufacturer's protocol. ${ }^{11}$

\section{Monocytes/Lymphocytes Chemotaxis Assays}

Transwell chemotaxis assays were performed as described with minor modifications. $^{12,13}$ PICs were seeded in the lower well; isolated monocytes/lymphocytes were labeled with fluorescence dye 1,1dioctadecyl-3,3,3',3'-tetramethylindocarbocyanine perchlorate and added to the top chamber. Migrated monocytes/lymphocytes were quantified by counting the number of fluorescent positive cells.

\section{Monocytes/Lymphocytes-Pericardial Interstitial Cells Adhesion Assay}

For the cell adhesion assay, ${ }^{14}$ isolated CD45 positive monocytes/lymphocytes were added onto the PIC monolayer and incubated for 30 minutes at $37^{\circ} \mathrm{C}$. The accumulation of adherent cells was quantified by counting under a microscope.

\section{Measurement of Inflammatory Cytokines Release}

For measurement of inflammatory cytokines release from the PICs in the medium, the media were collected from the plates of PICs after 48 hours of culture. The concentrations of inflammatory cytokines in the media were measured using enzyme-linked immunosorbent assay.

\section{Measurement of Collagen}

Collagen content was determined through a colorimetric reaction against Picrosirius red. ${ }^{15}$ Briefly, PICs were lysed, dried, and stained with Picrosirius red $(0.1 \% \mathrm{w} / \mathrm{v}$ in saturated picric acid) for 1 hour at room temperature. Subsequently, the samples were washed by $0.1 \mathrm{~mol} / \mathrm{L}$ $\mathrm{HCl}$ and dissolved in $0.5 \mathrm{~mol} / \mathrm{L} \mathrm{NaOH}$. The plates were read by spectrophotometer at an absorbance of $570 \mathrm{~nm}$. Collagen content was expressed as arbitrary units per microgram of protein.

\section{Calcification Induction}

Calcium phosphate crystals were extracted from calcified pericardia as previously described. ${ }^{16}$ Crystals conditioned medium was prepared using Dulbecco's modified Eagle's medium supplemented with 5\% fetal bovine serum and $150 \mu \mathrm{g} / \mathrm{mL}$ calcium phosphate crystals. For calcification induction, the cells at confluence were switched to crystal-conditioned medium or calcification-inducing medium. ${ }^{17}$

\section{Flow Cytometric Analysis of Apoptosis}

Apoptosis was determined using flow cytometry by Annexin V-fluorescein isothiocyanate/propidium iodide staining.

\section{Mineralization Detection and Quantification}

Mineralization was detected with Von Kossa staining. To quantify calcium deposition, cells were decalcified with $0.6 \mathrm{~N} \mathrm{HCl}$ for 24 hours. The calcium content of the $\mathrm{HCl}$ supernatant was determined colorimetrically by the 0 -cresolphthalein complexone method (Calcium kit; Sigma, St Louis, Mo). Protein content was measured with a BCA protein assay kit (Pierce, Waltham, Mass). Calcium content was normalized by protein content and was calculated as $\mu \mathrm{g} / \mathrm{mg}$ protein.

\section{Statistical Analysis}

Data are expressed as the mean \pm standard deviation, and statistical analysis was performed with GraphPad software (GraphPad Software Inc, La Jolla, Calif). Normally distributed variables were analyzed using paired Student $t$ test, and non-normally distributed variables were analyzed using the Wilcoxon signed-rank test.

\section{RESULTS}

\section{Telomere Shortening and Decreased Growth Capacity of Pericarditis Pericardial Interstitial Cells In Vitro}

To ascertain whether PIC senescence had already occurred in IPCP, we first compared telomere length between freshly isolated pericarditis (passage 2) and nonpericarditis PICs (passage 2). Telomere length assessment by qPCR showed that pericarditis PICs had a significantly shorter telomere length compared with the nonpericarditis PICs (Figure 1, A). Microscopically, they exhibited the morphologic features of senescence, as evidenced by the flattened and enlarged morphology with an increased 


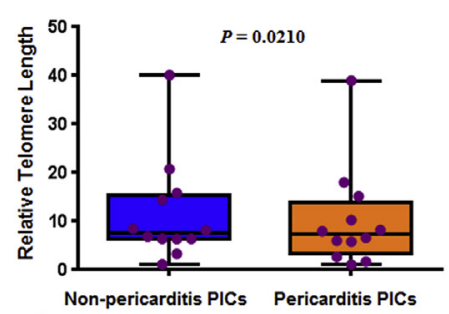

A

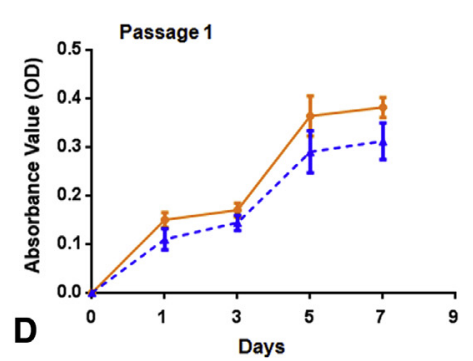

B
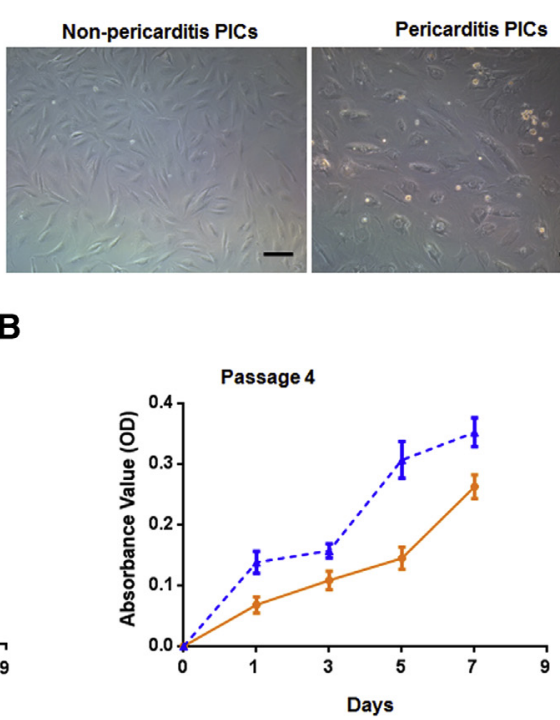

Pericarditis PICs

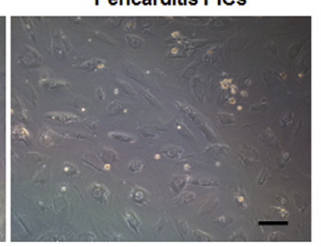

C
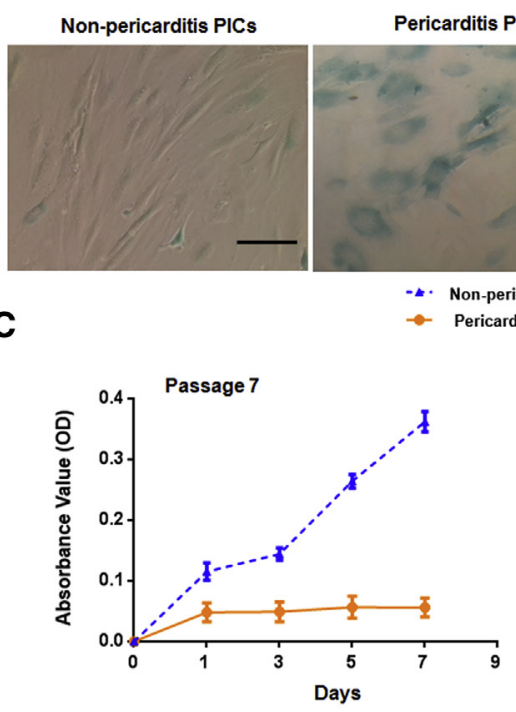

FIGURE 1. Pericarditis PICs derived from patients with IPCP displayed senescent changes. Telomere length was evaluated using qPCR (A). The boundaries of the boxes represent the first and third quartiles, the horizontal line within the boxes represents the median, and the ends of the whiskers represent the minimum and maximum values. Dots represent data points. The senescence of PICs was determined by morphologic features (B) and SA- $\beta$-gal staining (C). Bar $=100 \mu \mathrm{m}$. Quantification of cellular proliferation was performed with the 3-(4,5-dimethylthiazol-2-yl)-2,5-diphenyltetrazolium bromide assay. PIC, Pericardial interstitial cell; $O D$, optical density values at $450 \mathrm{~nm}$.

cytoplasmic granularity (Figure $1, B$ ) and increased SA- $\beta$ gal activity (Figure 1,C). More important, the pericarditis PICs exhibited limited growth capacity in vitro, proliferated more rapidly in the early stages (passage 1), grew at a reduced rate at later passages (approximately passage 4), and underwent complete growth arrest by approximately passage 14 (Figure 1, D). Nonpericarditis PICs began senescing after passage 8 to 9 and reached complete growth arrest by approximately passage 25 .

\section{Senescent Pericardial Interstitial Cells Show a Proinflammatory Phenotype}

Microscopically, the number of fluorescent-labeled cells that migrated toward senescent PICs was significantly greater than that toward nonsenescent PICs $(\sim 3.2$-fold) (Figure 2, A). We next tested whether senescent PICs possessed a higher ability to adhere monocytes/lymphocytes, and the results showed that only a few of the monocytes/lymphocytes adhered to the surface of nonsenescent PICs (Figure 2, B). However, an increased number of monocytes/lymphocytes was observed around the senescent PICs, with an average of 6 monocytes/lymphocytes adhered to each PIC.

Relative to controls, senescent PICs expressed higher levels of interleukin-6 (8-fold), monocyte chemoattractant protein (MCP)-1 (2-fold), and tumor necrosis factor- $\alpha$ (TNF- $\alpha$ ) (54-fold), whereas interleukin-8 expression levels were similar (Figure 2,C). Consistent with increased mRNA expression, TNF- $\alpha(370 \pm 50 \mathrm{pg} / \mathrm{mL}$ vs $269 \pm 56$ $\mathrm{pg} / \mathrm{mL}, P=.0034)$ protein levels were increased in the senescent PIC cell supernatant compared with controls, but interleukin-6 $(110 \pm 9 \mathrm{pg} / \mathrm{mL}$ vs $89 \pm 25 \mathrm{pg} / \mathrm{mL}$, $P=.1250)$ and MCP-1 $(115 \pm 10 \mathrm{pg} / \mathrm{mL}$ vs $99 \pm 12 \mathrm{pg} /$ $\mathrm{mL}, P=.0625)$ levels were not significantly greater.

However, there was no difference in mRNA levels of adhesion molecules including endothelial-leukocyte adhesion molecule-1 $(P=.0776)$, vascular cell adhesion molecule-1 $(P=.1605)$, or intracellular adhesion molecule-1 $(P=.9763)$ between senescent and nonsenescent PICs (Figure 2, $C$ ).

\section{Senescent Pericardial Interstitial Cells Execute a Profibrotic Program}

Quantitative analysis of collagen content showed that collagen accumulation was significantly higher in senescent PICs than in nonsenescent PICs (Figure 3, A), suggesting that senescent PICs may be the source of initiation and maintenance of extracellular matrix (ECM) deposition.

Furthermore, mRNA levels of connective tissue growth factor (5.3-fold), fibronectin (3.4-fold), collagen type I (3.9-fold), and collagen type III (3.4-fold) were significantly upregulated in senescent PICs compared with the controls (Figure 3, B). However, there was no difference in mRNA levels of the myofibroblastic phenotypic markers, $\operatorname{desmin}(P=.1747)$, and SM22 $(P=.7430)$ between senescent and nonsenescent PICs.

In addition, qPCR showed that matrix metalloproteinase (MMP)-1 and MMP-3 were downregulated to 

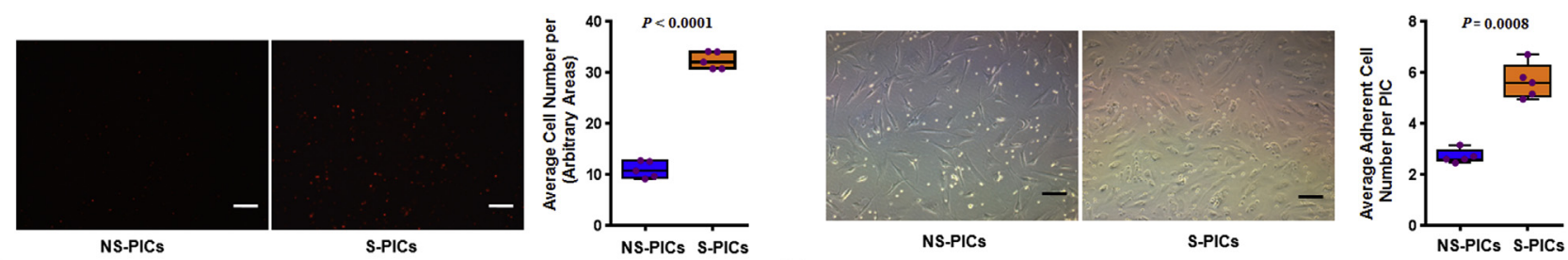

A
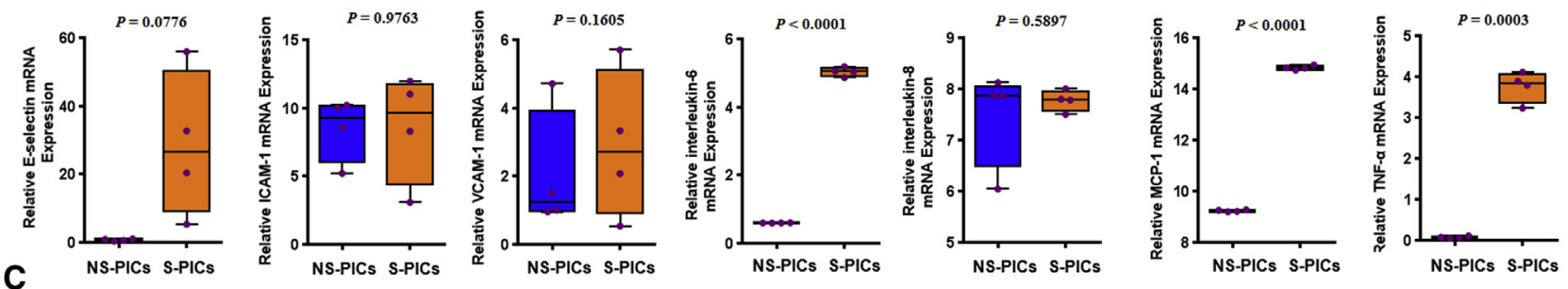

FIGURE 2. Senescent PICs expressed specific inflammatory genes and recruited inflammatory cells. Chemotactic migration and adhesion of monocytes/ lymphocytes were assessed with a transwell migration assay (A) and adhesion assay (B), respectively. Bar $=100 \mu \mathrm{m}$. The differential expression of inflammation-related factors was analyzed by qPCR (C). The boundaries of the boxes represent the first and third quartiles, the horizontal line within the boxes represents the median, and the ends of the whiskers represent the minimum and maximum values. Dots represent data points. NS-PICs, Nonsenescent pericardial interstitial cells; S-PICs, senescent pericardial interstitial cells; ICAM-1, intracellular adhesion molecule-1; VCAM-1, vascular cell adhesion molecule-1; $M C P$, chemoattractant protein; $T N F-\alpha$, tumor necrosis factor- $\alpha$.

approximately $61 \%$ and $26 \%$, respectively, although tissue inhibitors of metalloproteinase (TIMP)-1 were upregulated 1.8-fold in senescent PICs compared with nonsenescent cells (Figure 3, B). These results, together with the results described earlier, suggest that senescent PICs express a profibrotic genetic program and may contribute to the development and progression of IPCP fibrosis.

\section{Senescent Pericardial Interstitial Cells Execute a Procalcific Program}

Both von Kassa staining (Figure 4, A) and colorimetric reaction (Figure $4, B$ ) showed that senescent PICs contained higher calcium deposition compared with nonsenescent cells under calcification-inducing culture conditions for 7 days, suggesting that senescent PICs may serve as the nuclei for calcium deposition and nodule formation.

As shown in Figure 4, $C$, the mRNA expression levels of matrix Gla protein (MGP, 9-fold), bone morphogenetic protein (BMP)-4 (70-fold), and noncollagenous bone-matrix proteins, including osteopontin (1.8-fold), bone sialoprotein (244-fold), and osteonectin (2.4-fold), were markedly enhanced in the senescent PICs compared with nonsenescent cells, although osteocalcin was not detected in PICs.

In addition, we found that senescent PICs were more likely to avoid apoptosis than nonsenescent cells after exposure to several apoptotic stimuli, including serum deprivation (Figure $4, D ; P=.0027$ ) and calcium phosphate crystals (Figure 4, $E ; P=.0013$ ), suggesting that senescent PICs contribute to the calcification process through an active "cell-mediated mechanism" resembling embryonic bone formation, not passive mineral precipitation.

\section{Senescent Pericardial Interstitial Cells Exert Paracrine Effects on Neighboring Pericardial Interstitial Cells}

Senescent medium-treated PICs grew faster than those treated with control medium, as early as 24 hours after treatment, and persisted up to the 7-day study period (Figure 5, $A$ ), suggesting a growth-enhancing effect of senescent PICs on their neighboring cells in a paracrine fashion. Furthermore, senescent medium increased mRNA transcription of $\alpha$-smooth muscle actin in nonsenescent PICs as early as day 3 (passage 2), although they inhibited the mRNA transcription of interleukin-6, MCP-1, and TNF- $\alpha$ (Figure 5, B). However, after 7 days, the mRNA level of TNF- $\alpha$ and alkaline phosphatase in the senescent medium-treated PICs increased, whereas interleukin-6 and MCP-1 continued to decline (Figure 5, C).

\section{DISCUSSION}

In this study, we demonstrated that pericarditis PICs derived from IPCP lesions displayed senescence-like changes, including short telomere length, large flattened cell sizes, positive staining for SA- $\beta$-gal, and limited growth capacity. Furthermore, in vitro functional studies showed that senescent PICs exhibited functional alterations showed selective regulation of specific fibrocalcific and inflammatory programs, and affected the neighboring cells through paracrine effects. These findings suggest that senescent PICs have characteristics promoting pericardial structural remodeling that involves pericardial inflammation, fibrosis, and calcification, and may be a possible mechanism contributing to the progression of IPCP. 


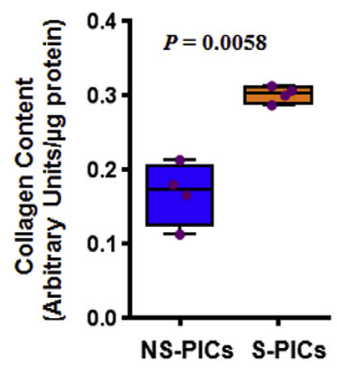

A

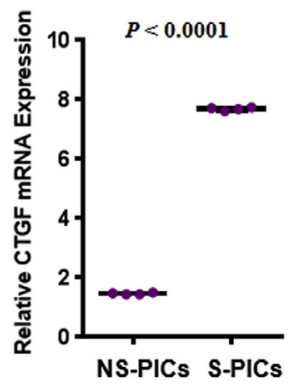

B

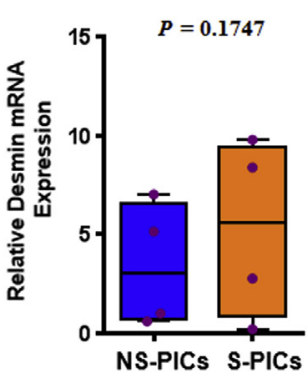

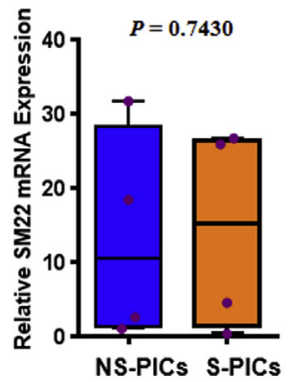
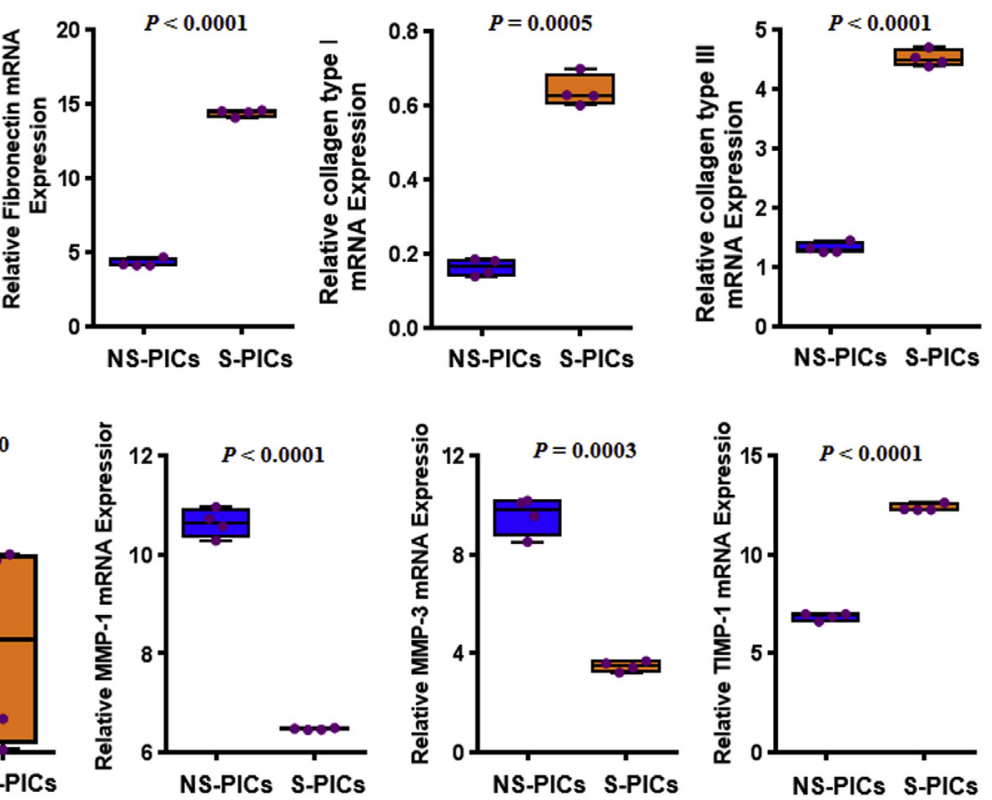

FIGURE 3. Senescent PICs modulated specific fibrotic genes and produced more collagen matrix. Collagen content was determined through a colorimetric reaction against Picrosirius red (A). The differential expression of fibrosis-related factors was analyzed by qPCR (B). The boundaries of the boxes represent the first and third quartiles, the horizontal line within the boxes represents the median, and the ends of the whiskers represent the minimum and maximum values. Dots represent data points. NS-PICs, Nonsenescent pericardial interstitial cells; S-PICs, senescent pericardial interstitial cells; CTGF, connective tissue growth factor; $S M$, senescent medium; $M M P$, matrix metalloproteinase; TIMP, tissue inhibitors of metalloproteinase.

The relationship between cellular senescence and inflammation has been extensively studied, and recent studies have demonstrated that senescent cells exhibit similar gene expression patterns as those observed in inflammatory responses and wound-healing processes. ${ }^{18,19}$ Of particular interest, cellular senescence, in some types of cells such as fibroblasts, ${ }^{18}$ hepatic satellite cells, ${ }^{20}$ and vascular smooth muscle cells, ${ }^{21}$ is characterized by high level secretion of multiple proinflammatory cytokines. In this study, we also demonstrated that senescent PICs expressed increased levels of proinflammatory cytokine genes, such as TNF- $\alpha$, interleukin-6, and MCP-1. As a member of cytokines, TNF- $\alpha$ has the ability to recruit circulating inflammatory cells to areas of inflammation and plays a key role in the initiation, regulation, and perpetuation of the inflammatory response. ${ }^{22}$ Interleukin$6^{23}$ and MCP- $1^{24}$ also are involved in local inflammatory responses, helping to attract and adhere inflammatory cells. Therefore, the upregulation of TNF- $\alpha$, interleukin6 , and MCP-1 may be the molecular mechanism that links inflammation and the senescent state in the setting of IPCP, suggesting that senescent PICs may play an active role in recruiting monocytes/lymphocytes to the pericardia and evoking inflammatory reactions.

It is generally believed that cardiovascular fibrosis is associated with an increase in ECM content and in particular with an increase in collagen deposition. ${ }^{25}$ The dynamic turnover of ECM components is controlled by several regulatory mechanisms, including de novo biosynthesis of ECM molecules, proteolytic degradation of collagens by MMPs, and inhibition of MMP activities by TIMPs. Our current data seem consistent with this paradigm that cellular senescence has a dual effect in the regulation of the fibrotic process. First, senescent PICs synthesized more ECM components than nonsenescent PICs. In addition, the decreased MMPs and increased TIMPs might favor less MMP activity, which would lead to less damage to the $\mathrm{ECM},{ }^{26}$ resulting in fibrosis. However, the data from previous studies of liver fibrosis are inconsistent with our results, which showed that senescence of activated hepatic stellate cells limits liver fibrosis. ${ }^{27}$ Schnabl and colleagues ${ }^{20}$ further demonstrated that hepatic stellate cells are characterized by a pronounced inflammatory but less fibrogenic phenotype. Taken together, these results suggest that the effect of cellular senescence on tissue fibrosis is cell-type specific.

The pathogenesis of cardiovascular calcification is currently believed to involve both passive and active processes. Passive mineralization is a deposition of supersaturated mineral in the region of cellular damage and degeneration, ${ }^{28}$ whereas the active process of calcification may share some mechanisms with mineralization observed in bone, cartilage, and teeth. ${ }^{29}$ In this study, our results demonstrated that senescent PICs contributed to the calcification process through an active "cell-mediated mechanism" resembling osteogenesis in bone, not a passive mineral precipitation. First, we found that senescent PICs 


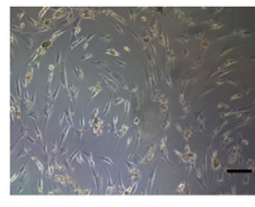

NS-PICs

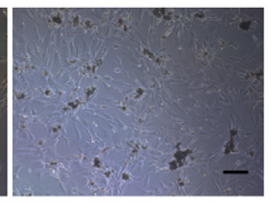

S-PICs

A

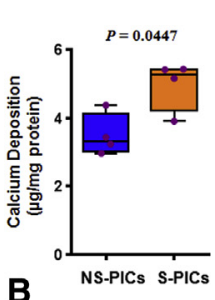

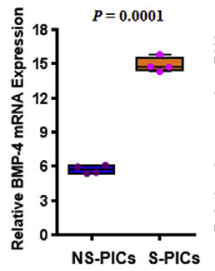
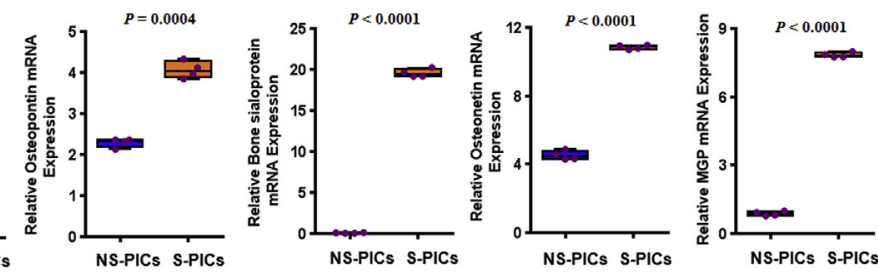

FIGURE 4. Senescent PICs regulated specific calcific genes and deposit more calcium. PICs were treated with crystal-conditioned medium (containing 5\% fetal bovine serum), and calcium deposition was detected by von Kassa staining (A) and calcium assay (B). Bar $=100 \mu \mathrm{m}$. The differential expression of calcification-related factors was analyzed by qPCR (C). PICs were treated with serum-free medium (D) or low-serum (0.5\% fetal bovine serum) crystals conditioned medium (E) for 24 hours. Apoptosis was measured by using flow cytometry. The boundaries of the boxes represent the first and third quartiles, the horizontal line within the boxes represents the median, and the ends of the whiskers represent the minimum and maximum values. Dots represent data points. NS-PICs, Nonsenescent pericardial interstitial cells; $S$-PICs, senescent pericardial interstitial cells; $B M P$, bone morphogenetic protein; $M G P$, matrix Gla protein; V-FITC, Annexin V-Fluorescein Isothiocyanate.

orchestrated the osteoblasts transdifferentiation program, which involved the increased transcription of osteoblast differentiation stimulating factors and noncollagenous bonematrix proteins. BMP can act on various cell types and elicit a response that is specific to osteoblast differentiation and bone formation. ${ }^{30}$ Noncollagenous bone-matrix proteins, such as osteopontin, bone sialoprotein, and osteonectin, functionally provide an ideal nucleation site for
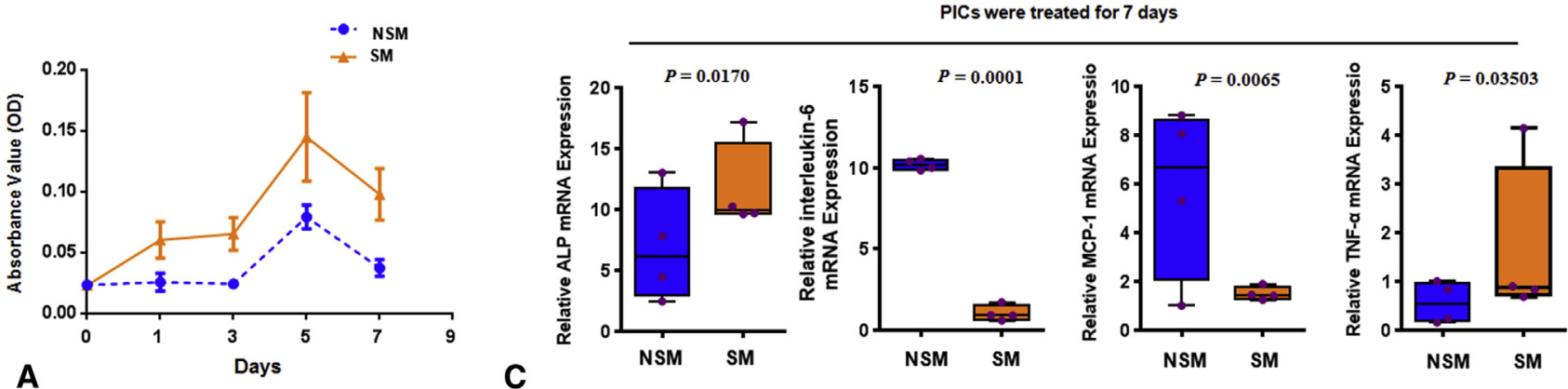

PICs were treated for 3 days
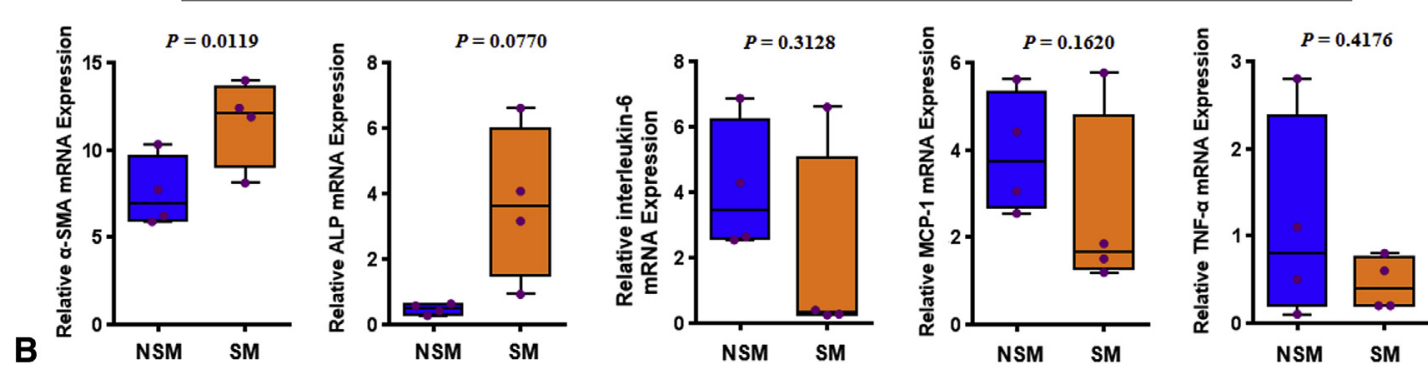

FIGURE 5. Senescent PICs had paracrine effects on their neighboring PICs. PICs were treated with senescent or control nonsenescent medium, and cell proliferation was determined by 3-(4,5-dimethylthiazol-2-yl)-2,5-diphenyltetrazolium bromide assay (A). The differential expression of differentiation and inflammation-related genes was analyzed by qPCR (B). The boundaries of the boxes represent the first and third quartiles, the horizontal line within the boxes represents the median, and the ends of the whiskers represent the minimum and maximum values. Dots represent data points. NSM, Nonsenescent medium; SM, senescent medium; $O D$, optical density values at $450 \mathrm{~nm}$. 
calcification within the calcifying microenvironment because of their ability to bind calcium and phosphate to cell surface. ${ }^{31-33}$ Paradoxically, senescent PICs also expressed increased levels of the calcification inhibitor, MGP. As a mineral-binding ECM protein, MGP strongly inhibits the precipitation of calcium salts and blocks the osteoinductive properties of BMP by direct binding. Although the mechanism responsible for the observed increase in MGP is not known, the MGP elevation in the senescent microenvironment may represent a protective response against an overwhelming dysregulation of the procalcification process. When this protective pathway is overwhelmed, senescent PICs may serve as the nuclei for mineral deposition and initiate pericardial calcification. It is noteworthy that passive mineral deposition may occur in areas of advanced tissue degeneration or necrosis ${ }^{34}$ because the debris of apoptotic or necrotic cells may locally concentrate calcium and phosphate, thus providing a suitable microenvironment for calcification. Contrary to our expectations, we found that senescent PICs were more likely to avoid apoptosis than nonsenescent cells after exposure to several apoptotic stimuli, suggesting that senescent PICs contribute to calcium deposits not by passive mineral deposition but through active de novo production of bone matrix molecules.
It is well recognized that cells approaching senescence develop a senescence-associated secretory phenotype (SASP), ${ }^{35,36}$ which increases the secretion of cytokines and growth factors that alter the behavior of neighboring cells. When these senescent cells are chronically present, some SASP factors may reinforce the senescence growth arrest for preventing the growth of damaged cells, which are at risk for malignant transformation. However, some SASP factors may disrupt normal tissue function and drive aging phenotypes, and contribute to several chronic degenerative diseases. For example, secreted mitogens stimulate neighboring cell growth, and inflammatory cytokines can stimulate inflammation. In the present study, we found that senescent PICs were more likely to avoid apoptosis than control cells on exposure to apoptotic stimuli, and their long-term existence may exert both beneficial and deleterious effects on neighboring PICs. On the one hand, senescent PIC medium stimulated neighboring PICs growth in vitro and thereby promoted tissue repair. On the other hand, senescent PIC medium accelerated the senescence of neighboring PICs, induced the myofibroblasts/osteoblasts transdifferentiation, and increased proinflammatory cytokine expression, which may reinforce the process of fibrosis, calcification, and inflammation.

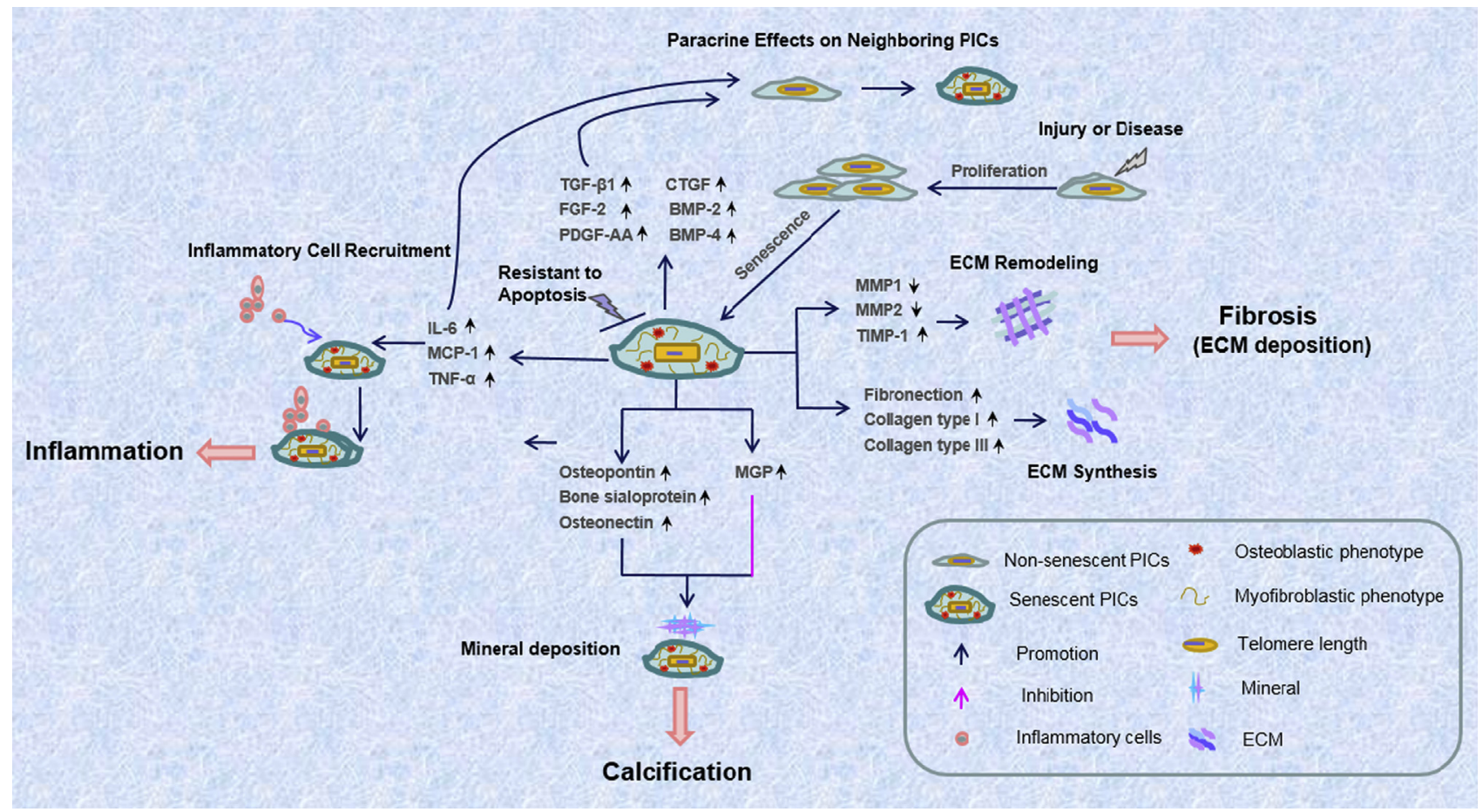

FIGURE 6. Proposed mechanism of PIC senescence responsible for pericardial structural remodeling. TGF, Tissue growth factor; $F G F-2$, Fibroblast growth factor-2; PDGF-AA, platelet-derived growth factor-AA; $C T G F$, connective tissue growth factor; $B M P$, bone morphogenetic protein; $E C M$, extracellular matrix; $I L$, interleukin; $M C P$, chemoattractant protein; $T N F-\alpha$, tumor necrosis factor- $\alpha$; $M M P$, matrix metalloproteinase; TIMP, tissue inhibitors of metalloproteinase; $M G P$, matrix Gla protein. 


\section{Potential Significance}

In our previous studies, ${ }^{6,7}$ we identified that many controlling factors (eg, transforming growth factor- $\beta 1$ ) may trigger the fibrocalcific progression via different pathways. Blocking 1 pathway may not be able to attenuate or eliminate pathologic progression given the complex pathologic conditions. Therefore, it is important to determine whether there is a common pathway among all the controlling factors.

On the basis of the present study and our previous studies, ${ }^{6,7}$ we found that PIC senescence is likely to be a common pathway that links the controlling factors with pericardial structural remodel (Figure 6). After disruption of the normal steady state of PICs, as occurs in association with pericardial injury or disease, quiescent PICs undergo a process of proliferation and active secretion accompanied by progressive telomere shortening to create a favorable environment for repair. Once telomeres reach a critically short length, PICs enter a senescent state and display a specific gene expression profile to promote pericardial structural remodel. Senescent PICs synthesize ECM components including collagen and fibronectin, modulate the expression of enzymes such as MMP/TIMP that mediate ECM remodeling, serve as the nuclei for mineral deposition by producing noncollagenous bone-matrix proteins, and secrete modulatory cytokines such as transforming growth factor- $\beta 1$, BMP-2, and BMP4, which can potentiate PIC pathologic differentiation to myofibroblast or osteoblast lineages; on the basis of these effects, they contribute to pericardial fibrocalcification. Senescent PICs produce proinflammatory cytokines that are potently capable of recruiting inflammation cells and thereby contribute to the early phases of pericardial inflammation. Furthermore, senescent PICs are relatively resistant to apoptosis and secrete paracrine factors that alter the behavior of neighboring cells (eg, proliferation, differentiation, and senescence) and reinforce pericardial structural remodeling.

\section{CONCLUSIONS}

These findings support the emerging hypothesis that PIC senescence may play an important role in the development of pericardial structural remodeling. We now need to uncover the mechanisms involved in PIC senescence and provide new avenues for the treatment of IPCP, especially for the prevention of postsurgical constrictive pericarditis.

\section{Conflict of Interest Statement}

Authors have nothing to disclose with regard to commercial support.

\section{References}

1. Oh KY, Shimizu M, Edwards WD, Tazelaar HD, Danielson GK. Surgical pathology of the parietal pericardium: a study of 344 cases (1993-1999). Cardiovasc Pathol. 2001;10:157-68.
2. Bertog SC, Thambidorai SK, Parakh K, Schoenhagen P, Ozduran V, Houghtaling PL, et al. Constrictive pericarditis: etiology and causespecific survival after pericardiectomy. J Am Coll Cardiol. 2004;43: 1445-52.

3. Talreja DR, Edwards WD, Danielson GK, Schaff HV, Tajik AJ, Tazelaar HD, et al. Constrictive pericarditis in 26 patients with histologically normal pericardial thickness. Circulation. 2003;108:1852-7.

4. Noureddine H, Gary-Bobo G, Alifano M, Marcos E, Saker M, Vienney N, et al. Pulmonary artery smooth muscle cell senescence is a pathogenic mechanism for pulmonary hypertension in chronic lung disease. Circ Res. 2011; 109:543-53.

5. Ragnauth CD, Warren DT, Liu Y, McNair R, Tajsic T, Figg N, et al. Prelamin A acts to accelerate smooth muscle cell senescence and is a novel biomarker of human vascular aging. Circulation. 2010;121:2200-10.

6. Liu XH, Bai CG, Gong DJ, Yuan Y, Han L, Lu FL, et al. Pleiotropic effects of TGF- $\beta 1$ on pericardial interstitial cells: implications for fibrosis and calcification in idiopathic constrictive pericarditis. J Am Coll Cardiol. 2011;57:1634-5.

7. Liu XH, Tan MW, Gong DJ, Han L, Lu FL, Huang SD, et al. Characteristics of pericardial interstitial cells and their implications in pericardial fibrocalcification. J Mol Cell Cardiol. 2012;53:780-9.

8. Tchirkov A, Lansdorp PM. Role of oxidative stress in telomere shortening in cultured fibroblasts from normal individuals and patients with ataxia-telangiectasia. Hum Mol Genet. 2003;12:227-32.

9. Svenson U, Nordfjäll K, Stegmayr B, Manjer J, Nilsson P, Tavelin B, et al. Breast cancer survival is associated with telomere length in peripheral blood cells. Cancer Res. 2008;68:3618-23.

10. Samsonraj RM, Raghunath M, Hui JH, Ling L, Nurcombe V, Cool SM. Telomere length analysis of human mesenchymal stem cells by quantitative PCR. Gene. 2013;519:348-55.

11. Fujiyama S, Amano K, Uehira K, Yoshida M, Nishiwaki Y, Nozawa Y, et al. Bone marrow monocyte lineage cells adhere on injured endothelium in a monocyte chemoattractant protein-1-dependent manner and accelerate reendothelialization as endothelial progenitor cells. Circ Res. 2003;93:980-9.

12. Fong AM, Premont RT, Richardson RM, Yu YR, Lefkowitz RJ, Patel DD. Defective lymphocyte chemotaxis in beta-arrestin2- and GRK6-deficient mice. Proc Natl Acad Sci U S A. 2002;99:7478-83.

13. Harrison JK, Fong AM, Swain PA, Chen S, Yu YR, Salafranca MN, et al. Mutational analysis of the fractalkine chemokine domain. Basic amino acid residues differentially contribute to CX3CR1 binding, signaling, and cell adhesion. $J$ Biol Chem. 2001;276:21632-41.

14. Yang XP, Mattagajasingh S, Su S, Chen G, Cai Z, Fox-Talbot K, et al. Fractalkine upregulates intercellular adhesion molecule-1 in endothelial cells through CX3CR1 and the Jak Stat5 pathway. Circ Res. 2007;101:1001-8.

15. Shan H, Zhang Y, Lu Y, Zhang Y, Pan Z, Cai B, et al. Downregulation of miR-133 and miR-590 contributes to nicotine-induced atrial remodelling in canines. Cardiovasc Res. 2009;83:465-72.

16. Ewence AE, Bootman M, Roderick HL, Skepper JN, McCarthy G, Epple M, et al. Calcium phosphate crystals induce cell death in human vascular smooth muscle cells: a potential mechanism in atherosclerotic plaque destabilization. Circ Res. 2008; 103:e28-34.

17. Zhang XW, Zhang BY, Wang SW, Gong DJ, Han L, Xu ZY, et al. Twist-related protein 1 negatively regulated osteoblastic transdifferentiation of human aortic valve interstitial cells by directly inhibiting runt-related transcription factor 2 . J Thorac Cardiovasc Surg. 2014;148:1700-8.

18. Shelton DN, Chang E, Whittier PS, Choi D, Funk WD. Microarray analysis of replicative senescence. Curr Biol. 1999;9:939-45.

19. Foreman KE, Tang J. Molecular mechanisms of replicative senescence in endothelial cells. Exp Gerontol. 2003;38:1251-7.

20. Schnabl B, Purbeck CA, Choi YH, Hagedorn CH, Brenner D. Replicative senescence of activated human hepatic stellate cells is accompanied by a pronounced inflammatory but less fibrogenic phenotype. Hepatology. 2003;37:653-64.

21. Burton DG, Giles PJ, Sheerin AN, Smith SK, Lawton JJ, Ostler EL, et al. Microarray analysis of senescent vascular smooth muscle cells: a link to atherosclerosis and vascular calcification. Exp Gerontol. 2009;44:659-65.

22. Chen C, Khismatullin DB. Synergistic effect of histamine and TNF- $\alpha$ on monocyte adhesion to vascular endothelial cells. Inflammation. 2013;36: 309-19.

23. Yudkin JS, Kumari M, Humphries SE, Mohamed-Ali V. Inflammation, obesity, stress and coronary heart disease: is interleukin-6 the link? Atherosclerosis. 2000;148:209-14. 
24. Carr MW, Roth SJ, Luther E, Rose SS, Springer TA. Monocyte chemoattractant protein 1 acts as a T-lymphocyte chemoattractant. Proc Natl Acad Sci U S A. 1994;91:3652-6.

25. Nakajima H, Nakajima HO, Salcher O, Dittiè AS, Dembowsky K, Jing S, et al. Atrial but not ventricular fibrosis in mice expressing a mutant transforming growth factor-beta(1) transgene in the heart. Circ Res. 2000;86:571-9.

26. Li YY, Feng Y, McTiernan CF, Pei W, Moravec CS, Wang P, et al. Downregulation of matrix metalloproteinases and reduction in collagen damage in the failing human heart after support with left ventricular assist devices. Circulation. 2001; 104:1147-52.

27. Krizhanovsky V, Yon M, Dickins RA, Hearn S, Simon J, Miething C, et al. Senescence of activated stellate cells limits liver fibrosis. Cell. 2008;134: 657-67.

28. Takei Y, Yamamoto H, Sato T, Otani A, Kozai M, Masuda M, et al. Stanniocalcin 2 is associated with ectopic calcification in $\alpha$-klotho mutant mice and inhibits hyperphosphatemia-induced calcification in aortic vascular smooth muscle cells. Bone. 2012;50:998-1005.

29. Raggi P, Callister TQ, Cooil B, He ZX, Lippolis NJ, Russo DJ, et al. Identification of patients at increased risk of first unheralded acute myocardial infarction by electron-beam computed tomography. Circulation. 2000;101:850-5.

30. Kingsley DM. What do BMPs do in mammals? Clues from the mouse short-ear mutation. Trends Genet. 1994;10:16-21.
31. Fitzpatrick LA, Severson A, Edwards WD, Ingram RT. Diffuse calcification in human coronary arteries. Association of osteopontin with atherosclerosis. J Clin Invest. 1994;94:1597-604.

32. Kalamajski S, Aspberg A, Lindblom K, Heinegård D, Oldberg A. Asporin com petes with decorin for collagen binding, binds calcium and promotes osteoblast collagen mineralization. Biochem J. 2009;423:53-9.

33. Zung P, Domenicucci C, Wasi S, Kuwata F, Sodek J. Osteonectin is a minor component of mineralized connective tissues in rat. Biochem Cell Biol. 1986; 64:356-62.

34. Derlin T, Wisotzki C, Richter U, Apostolova I, Bannas P, Weber C, et al In vivo imaging of mineral deposition in carotid plaque using $18 \mathrm{~F}$-sodium fluoride PET/CT: correlation with atherogenic risk factors. J Nucl Med. 2011:52:362-8.

35. Campisi J, Andersen JK, Kapahi P, Melov S. Cellular senescence: a link between cancer and age-related degenerative disease? Semin Cancer Biol. 2011;21:354-9.

36. Zhang Y, Herbert BS, Rajashekhar G, Ingram DA, Yoder MC, Clauss M, et al Premature senescence of highly proliferative endothelial progenitor cells is induced by tumor necrosis factor-alpha via the p38 mitogen-activated protein kinase pathway. FASEB J. 2009;23:1358-65.

Key Words: constrictive pericarditis, pericardial interstitial cell, senescence, structural remodeling

Readers who found these articles interesting may also like to read the following papers found in recent and future issues of our sister publications, Seminars in Thoracic and Cardiovascular Surgery and Operative Techniques in Thoracic and Cardiovascular Surgery!

\section{Acquired: Basic Science}

ORIGINAL SUBMISSION: Immediate Spinal Cord Collateral Blood Flow During Thoracic Aortic Procedures: The Role of Epidural Arcades. Fabian A. Kari. Semin Thoracic Surg 2016:378-387.

Editorial Commentary: Spinal Cord Collateral Pathways-The Road Not Taken. Abe DeAnda Jr and Patrick T. Roughneen. Semin Thoracic Surg 2016:388-389. 


\section{SUPPLEMENTARY METHODS \\ Definition and Classification}

IPCP was defined according to previous publications. ${ }^{\mathrm{E} 1, \mathrm{E} 2}$ Patients were classified into the idiopathic group if they had no known or documented infections (viral, tuberculosis, fungal), acute myocardial infarction (acute, delayed), neoplasm, postcardiac injury syndrome (trauma, cardiothoracic surgery), systemic autoimmune disease (systemic lupus erythematosus, rheumatoid arthritis, ankylosing spondylitis, systemic sclerosing periarteritis nodosa, Reiter's syndrome), or history of mediastinal radiation. Postsurgical constriction was defined as constrictive pericarditis after prior cardiac surgery or trauma. According to this definition, patients were classified in the idiopathic and postsurgical subgroups.

\section{Telomere Length Measurement by Quantitative Real-Time Polymerase Chain Reaction}

Telomere length assessment was performed using a PCR. Briefly, genomic DNA was extracted from PICs, and the reference cell line human embryonic kidney 293 cells using a commercial kit (AxyPrep Multisource Genomic DNA Miniprep Kit; Axygen Biosciences, Union City, Calif).

Two separate PCR runs were performed for each sample: the first to determine the cycle threshold value for telomere amplification and the second to determine the cycle threshold value for control gene ( $\beta$-globin on chromosome 11) amplification. The primers used are listed in Table E3.

Telomere sequences were amplified in an ABI 7500 Fast Real-Time PCR System (Applied Biosystems, Foster City, Calif) using the following condition ${ }^{\mathrm{E} 3}: 95^{\circ} \mathrm{C}, 10$ minutes, to activate Taq polymerase; 35 cycles of denaturation at $95^{\circ} \mathrm{C}, 15$ seconds, and annealing/extension at $54^{\circ} \mathrm{C}, 2 \mathrm{mi}-$ nutes. The conditions for HBG gene amplification were $95^{\circ} \mathrm{C}, 10$ minutes; 40 cycles at $95^{\circ} \mathrm{C}, 15$ seconds; and $58^{\circ} \mathrm{C}, 1$ minute.

$\mathrm{T} / \mathrm{S}$ copy gene values were calculated by $2^{\Delta-\mathrm{Ct}}$, and relative $\mathrm{T} / \mathrm{S}$ values were generated by dividing sample $\mathrm{T} / \mathrm{S}$ values with the T/S value of a reference cell line DNA according to the reference method. ${ }^{\mathrm{E} 4, \mathrm{E} 5}$

\section{RNA Isolation, Reverse Transcription Polymerase Chain Reaction, and Quantitative Real-Time \\ Polymerase Chain Reaction}

Total RNA was isolated and purified using Trizol reagent (Invitrogen, Carlsbad, Calif), quantified with the NanoDrop 1000 spectrophotometer (NanoDrop Technologies, Wilmington, Del), and reverse transcribed into cDNA using PrimeScrip RT Reagent Kit (TaKaRa, Tokyo, Japan). cDNA conversion mixtures were subjected to PCR amplification for 40 cycles. qPCR was performed in an ABI 7500 Fast Real-Time PCR System (Applied Biosystems) using the SYBR Green Real-Time PCR Master Mix (TaKaRa).
Standard curves were established with SYBR Green I kit (Roche, Basel, Switzerland). 18S ribosomal RNA was used as a control gene to normalize the data. The primers used are listed in Table E3.

\section{Isolation of CD45-Positive Monocytes/Lymphocytes}

Human peripheral blood mononuclear cells were obtained from healthy volunteers and isolated on FicollHypaque density gradient centrifugation. CD45-positive monocytes/lymphocytes were subsequently sorted by use of magnetic beads. ${ }^{\mathrm{E} 6}$ Briefly, the cell suspensions were incubated with a mouse anti-human CD45 monoclonal antibody for 1 hour at $4^{\circ} \mathrm{C}$, followed by a phosphate-buffered saline (containing $0.1 \%$ bovine serum albumin) wash. Then, the cell suspensions were incubated with goat antimouse immunoglobulin-G-coated paramagnetic beads (Dynal, Oslo, Norway) for 30 minutes at $4^{\circ} \mathrm{C}$. After washing with phosphate-buffered saline (containing $0.1 \%$ bovine serum albumin), CD45-positive cells were sorted according to the manufacturer's protocol.

\section{Monocytes/Lymphocytes-Endothelial Cell Adhesion Assay}

In cell adhesion assay, ${ }^{\mathrm{E} 7} \mathrm{PICs}$ were seeded into 6-well plates $\left(5 \times 10^{4}\right.$ cells/well) and cultured for 48 hours until they formed a monolayer. Isolated monocytes/lymphocytes were added onto the PIC monolayer $\left(2 \times 10^{5}\right.$ cells in serumfree medium/well) and incubated for 30 minutes at $37^{\circ} \mathrm{C}$ in a cell culture incubator. The nonadhering cells were washed off, and the adhered monocytes/lymphocytes cells were determined by counting the cells adhered to each PIC $(\mathrm{n}=100)$ in random high-powered fields under an inverted microscope.

\section{Calcification Induction}

Calcium phosphate crystals extracted from calcified pericardia according to the method of Ewence and colleagues. ${ }^{\mathrm{E}}$ Briefly, the hardened, obviously calcified regions were dissected from samples of human calcific pericardia and digested with collagenase (Sigma [St Louis, Mo], type II $2 \mathrm{mg} / \mathrm{mL}$ ) overnight at $37^{\circ} \mathrm{C}$. After digestion, the crystals were washed 3 times in Hank's Balanced Salt Solution. Samples were then placed on a $70-\mu \mathrm{m}$ sieve (Gibco, Grand Island, NY) and washed further. The remaining crystals $(>70 \mu \mathrm{m})$ were crushed using a pestle and mortar into Dulbecco's modified Eagle's medium (DMEM). Washing of the crystals at this stage was achieved using ultracentrifugation at $100000 \mathrm{~g}$ to capture very small particles. Crystal-conditioned medium was prepared using DMEM supplemented with $5 \%$ fetal bovine serum and $150 \mu \mathrm{g} /$ $\mathrm{mL}$ calcium phosphate crystals.

For calcification induction, the cells at confluence were switched to crystal-conditioned medium or calcification- 
inducing medium. This calcification-inducing medium ${ }^{\mathrm{E} 9}$ consisted of complete growth medium supplemented with $50 \mathrm{ng} / \mathrm{mL}$ bone morphogenic protein-2, $50 \mathrm{mg} / \mathrm{mL}$ ascorbate-2- phosphate, $10 \mathrm{nmol} / \mathrm{L}$ dexamethasone, and $10 \mathrm{mmol} / \mathrm{Lb}$-glycerol phosphate. The appearance of the reaction product was monitored under the microscope, and the calcium deposition was detected by von Kossa staining and colorimetric method.

\section{Flow Cytometric Analysis of Apoptosis}

To induce apoptosis, the cells were incubated for 24 hours in serum-free DMEM or low-serum crystals conditioned medium (DMEM supplemented with $0.5 \%$ fetal bovine serum and $150 \mu \mathrm{g} / \mathrm{mL}$ calcium phosphate crystals). Apoptosis was detected using an annexin V-fluorescein isothiocyanate staining kit (R\&D Systems, Minneapolis, Minn). Briefly, cells were harvested by trypsinization and labeled with annexin V-fluorescein isothiocyanate and propidium iodide for 10 minutes at $4^{\circ} \mathrm{C}$, and analyzed using a FACSCalibur flow cytometer (BD Biosciences, Singapore). The apoptotic index is reported as the percentage of annexin V-positive cells in early and late stages of apoptosis.

\section{Mineralization Staining}

Mineralization was detected with Von Kossa staining, as described by Proudfoot and colleagues. ${ }^{\text {E10 }}$ Briefly, 3.7\% formaldehyde-fixed cells were incubated with $5 \%$ silver nitrate for 1 hour at room temperature in the dark, rinsed in double-distilled water, and exposed to strong light to visualize calcium deposits.

\section{E-References}

E1. Deterling RA Jr, Humphreys GH II. Factors in the etiology of constrictive pericarditis. Circulation. 1955;12:30-43.

E2. Bertog SC, Thambidorai SK, Parakh K, Schoenhagen P, Ozduran V, Houghtaling PL, et al. Constrictive pericarditis: etiology and causespecific survival after pericardiectomy. J Am Coll Cardiol. 2004;43 $1445-52$.

E3. Grabowski P, Hultdin M, Karlsson K, Tobin G, Aleskog A, Thunberg U, et al. Telomere length as a prognostic parameter in chronic lymphocytic leukemia with special reference to VH gene mutation status. Blood. 2005;105: 4807-12.

E4. Svenson U, Nordfjäll K, Stegmayr B, Manjer J, Nilsson P, Tavelin B, et al. Breast cancer survival is associated with telomere length in peripheral blood cells. Cancer Res. 2008;68:3618-23.

E5. Samsonraj RM, Raghunath M, Hui JH, Ling L, Nurcombe V, Cool SM. Telomere length analysis of human mesenchymal stem cells by quantitative PCR. Gene. 2013;519:348-55.

E6. Fujiyama S, Amano K, Uehira K, Yoshida M, Nishiwaki Y, Nozawa Y, et al. Bone marrow monocyte lineage cells adhere on injured endothelium in a monocyte chemoattractant protein-1-dependent manner and accelerate reendothelialization as endothelial progenitor cells. Circ Res. 2003;93: 980-9.

E7. Yang XP, Mattagajasingh S, Su S, Chen G, Cai Z, Fox-Talbot K, et al. Fractalkine upregulates intercellular adhesion molecule-1 in endothelial cells through CX3CR1 and the Jak Stat5 pathway. Circ Res. 2007;101: 1001-8.

E8. Ewence AE, Bootman M, Roderick HL, Skepper JN, McCarthy G, Epple M, et al. Calcium phosphate crystals induce cell death in human vascular smooth muscle cells: a potential mechanism in atherosclerotic plaque destabilization. Circ Res. 2008;103:e28-34.

E9. Zhang XW, Zhang BY, Wang SW, Gong DJ, Han L, Xu ZY, et al. Twist-related protein 1 negatively regulated osteoblastic transdifferentiation of human aortic valve interstitial cells by directly inhibiting runtrelated transcription factor 2. J Thorac Cardiovasc Surg. 2014;148: 1700-8.

E10. Proudfoot D, Skepper JN, Shanahan CM, Weissberg PL. Calcification of human vascular cells in vitro is correlated with high levels of matrix Gla protein and low levels of osteopontin expression. Arterioscler Thromb Vasc Biol. 1998; 18:379-88. 
TABLE E1. Baseline characteristics and pathologic measures

\begin{tabular}{|c|c|c|c|c|c|c|c|c|c|}
\hline \multirow[b]{2}{*}{ Patient no. } & \multirow[b]{2}{*}{ Age (y) } & \multirow[b]{2}{*}{ Sex } & \multirow[b]{2}{*}{ Cause } & \multirow[b]{2}{*}{ NYHA class } & \multirow[b]{2}{*}{$\mathrm{CVP}(\mathrm{mm} \mathrm{Hg})$} & \multicolumn{4}{|c|}{ Surgical pathology } \\
\hline & & & & & & PT (mm) & Fibrosis & Calcification & Inflammation \\
\hline 1 & 65 & M & I & 4 & 25 & 3 & Marked & Absent & Mild \\
\hline 2 & 45 & M & I & 4 & 20 & 5 & Marked & Absent & Marked \\
\hline 3 & 23 & M & I & 3 & 16 & 2 & Marked & Gross and microscopic & Moderate \\
\hline 4 & 44 & M & $\mathrm{P}$ & 4 & 18 & 4 & Marked & Absent & Moderate \\
\hline 5 & 71 & M & $\mathrm{P}$ & 4 & 23 & 5 & Marked & Gross and microscopic & Moderate \\
\hline 6 & 33 & $\mathrm{~F}$ & I & 2 & 20 & 8 & Marked & Gross and microscopic & Marked \\
\hline 7 & 52 & M & $\mathrm{P}$ & 4 & 22 & 3 & Moderate & Gross and microscopic & Marked \\
\hline 8 & 61 & M & I & 3 & 37 & 6 & Marked & Microscopic only & Absent \\
\hline 9 & 63 & M & I & 2 & 14 & 5 & Marked & Gross and microscopic & Mild \\
\hline 10 & 72 & M & I & 4 & 30 & 3 & Marked & Gross and microscopic & Mild \\
\hline 11 & 59 & M & I & 1 & 23 & 4 & Marked & Microscopic only & Mild \\
\hline 12 & 66 & M & I & 4 & 24 & 8 & Moderate & Absent & Marked \\
\hline Mean or n $(\%)$ & 55 & $\mathrm{M}(92 \%)$ & I $(75 \%)$ & 3.25 & 22.67 & 4.67 & & & \\
\hline
\end{tabular}

NYHA, New York Heart Association; $C V P$, central venous pressure; $P T$, pericardial thickness; $M$, male; $I$, idiopathic; $P$, postsurgical; $F$, female.

TABLE E2. Baseline characteristics of control patients

\begin{tabular}{lcclc}
\hline Control patient no. & Age $(\mathbf{y})$ & Sex & Cause (operation) & Matched IPCP patients \\
\hline 1 & 65 & $\mathrm{M}$ & Infective endocarditis (aortic valve replacement) & IPCP No.1 \\
2 & 45 & $\mathrm{M}$ & Advanced mitral incompetence (mitral valve replacement) & IPCP No.2 \\
3 & 23 & $\mathrm{M}$ & Dissecting aneurysm of the thoracic aorta (autopsy) & IPCP No.3 \\
4 & 44 & $\mathrm{M}$ & Reoperative aortic valve replacement & IPCP No.4 \\
5 & 71 & $\mathrm{M}$ & Reoperative coronary artery bypass grafting & IPCP No.5 \\
6 & 33 & $\mathrm{~F}$ & Ventricular septal defect (repair) & IPCP No.6 \\
7 & 52 & $\mathrm{M}$ & Reoperative aortic valve replacement & IPCP No.7 \\
8 & 61 & $\mathrm{M}$ & Aortic stenosis (aortic valve replacement) & IPCP No.8 \\
9 & 63 & $\mathrm{M}$ & Aortic stenosis (aortic valve replacement) & IPCP No.9 \\
10 & 72 & $\mathrm{M}$ & Aortic stenosis (aortic valve replacement with coronary artery bypass & IPCP No.10 \\
& & & grafting) & IPCP No.11 \\
11 & 59 & $\mathrm{M}$ & Mitral stenosis (mitral valve replacement) & IPCP No.12 \\
\hline
\end{tabular}


TABLE E3. Oligonucleotide primer sequences and lengths of the expected polymerase chain reaction products

\begin{tabular}{|c|c|}
\hline Gene & Primer sequences \\
\hline \multirow[t]{2}{*}{ TEL } & $5^{\prime}$ GGTTTTTGAGGGTGAGGGTGAGGGTGAGGGTGAGGGT 3' \\
\hline & $5^{\prime}$ TCCCGACTATCCCTATCCCTATCCCTATCCCTATCCCTA $3^{\prime}$ \\
\hline \multirow[t]{2}{*}{$\mathrm{hBG}$} & $5^{\prime}$ GCTTCTGACACAACTGTGTTCACTAGC $3^{\prime}$ \\
\hline & $5^{\prime}$ CACCAACTTCATCCACGTTCACC $3^{\prime}$ \\
\hline \multirow[t]{2}{*}{$\alpha$-SMA } & $5^{\prime}$ TTTGGCTTGGCTTGTCAGG 3' \\
\hline & $5^{\prime}$ GGACAGGAATTGAAGCGGAA $3^{\prime}$ \\
\hline \multirow[t]{2}{*}{ ALP } & $5^{\prime}$ TGCCATCCTGTATGGCAATG $3^{\prime}$ \\
\hline & $5^{\prime}$ CAGACTGCGCCTGGTAGTTGT $3^{\prime}$ \\
\hline \multirow[t]{2}{*}{ E-selectin } & $5^{\prime}$ GCCTTGAATCAGATGGAAGC $3^{\prime}$ \\
\hline & $5^{\prime}$ GGCATCTGGCATAGTAGGCA $3^{\prime}$ \\
\hline \multirow[t]{2}{*}{ VCAM-1 } & $5^{\prime}$ TGGAGGATGCAGACAGGAAG $3^{\prime}$ \\
\hline & $5^{\prime}$ ACAGAGCCACCTTCTTGCAG $3^{\prime}$ \\
\hline \multirow[t]{2}{*}{ ICAM-1 } & $5^{\prime}$ GCAAGGTGACCGTGAATGTG $3^{\prime}$ \\
\hline & $5^{\prime}$ TTCCGCTGGCGGTTATAGAG $3^{\prime}$ \\
\hline \multirow[t]{2}{*}{ IL-6 } & $5^{\prime}$ TGGCTGCAGGACATGACAAC $3^{\prime}$ \\
\hline & 5' CAATCTGAGGTGCCCATGCT $3^{\prime}$ \\
\hline \multirow[t]{2}{*}{ IL-8 } & $5^{\prime}$ TCCAAGCTGGCCGTGGCTCT $3^{\prime}$ \\
\hline & $5^{\prime}$ CTGTGTTGGCGCAGTGTGGTC $3^{\prime}$ \\
\hline \multirow[t]{2}{*}{ MCP-1 } & 5' GTCTCTGCCGCCCTTCTGTGC $3^{\prime}$ \\
\hline & $5^{\prime}$ AACAGCAGGTGACTGGGGCAT $3^{\prime}$ \\
\hline \multirow[t]{2}{*}{ TNF- $\alpha$} & $5^{\prime}$ CCCTGTGAGGAGGACGAA $3^{\prime}$ \\
\hline & $5^{\prime}$ GAAGTGGTGGTCTTGTTGC $3^{\prime}$ \\
\hline \multirow{2}{*}{ CTGF } & $5^{\prime}$ CCAACCGCAAGATCGGCGTG $3^{\prime}$ \\
\hline & $5^{\prime}$ AGTCAGGGCTGGGCAGACGA $3^{\prime}$ \\
\hline \multirow[t]{2}{*}{ Fibronectin } & $5^{\prime}$ AGAAGTGGTCCCTCGGCCCC $3^{\prime}$ \\
\hline & $5^{\prime}$ ACCAGTTGGGGAAGCTCGTCTGT 3' \\
\hline \multirow[t]{2}{*}{ Collagen I } & $5^{\prime}$ GAGCGGACGCTAACCCCCTCC $3^{\prime}$ \\
\hline & $5^{\prime}$ GCCGTTGTCGCAGACGCAGAT $3^{\prime}$ \\
\hline \multirow[t]{2}{*}{ Collagen III } & 5' GGTCCTCCTGGCCCTCCTGG 3' \\
\hline & $5^{\prime}$ CCCGGGCTCCCATCAGTCCA $3^{\prime}$ \\
\hline \multirow[t]{2}{*}{ Desmin } & $5^{\prime}$ AGATTGCCACCTACCGGAAG $3^{\prime}$ \\
\hline & $5^{\prime}$ TGTGTGGCCTCACTGACGAC $3^{\prime}$ \\
\hline \multirow[t]{2}{*}{ SM22 } & $5^{\prime}$ GAAGGCGGCTGAGGACTATG $3^{\prime}$ \\
\hline & 5' CTCTGCACTGCTGCCATGTC $3^{\prime}$ \\
\hline \multirow[t]{2}{*}{ MMP-1 } & 5'AGACAAAGGCAAGTTGAAAAGCGGA $3^{\prime}$ \\
\hline & 5' TTGCTCCCAGCGAGGGTTCC $3^{\prime}$ \\
\hline \multirow[t]{2}{*}{ MMP-3 } & $5^{\prime}$ TGGAGCCAGGCTTTCCCAAGCA $3^{\prime}$ \\
\hline & 5' CTCGAGTCACAGCACAGGCAGG 3' \\
\hline \multirow[t]{2}{*}{ TIMP-1 } & 5' GTCCCGTCACCTTGCCTGCC $3^{\prime}$ \\
\hline & $5^{\prime}$ GCTTCAGCTTCCACTCCGGGC $3^{\prime}$ \\
\hline \multirow[t]{2}{*}{ Osteoponin } & $5^{\prime}$ GCCTTCTCAGCCAAACGCCGA $3^{\prime}$ \\
\hline & 5' CTTGGAAGGGTCTGTGGGGCT $3^{\prime}$ \\
\hline Bone sialoprotein & $5^{\prime}$ ACGGGGAACCTCGTGGGGAC $3^{\prime}$ \\
\hline & 5' AGGCTGGAGCTTCACTGGTGGT $3^{\prime}$ \\
\hline Osteonectin & $5^{\prime}$ TCCACTGCGTGCTCCCCTCA $3^{\prime}$ \\
\hline & $5^{\prime}$ GAAGCAGCCGGCCCACTCAT $3^{\prime}$ \\
\hline Osteocalcin & $5^{\prime}$ ATTGGCCCTGGCCGCACTTTG $3^{\prime}$ \\
\hline & $5^{\prime}$ GCTCCAGGGGATCCGGGTAGG $3^{\prime}$ \\
\hline MGP & 5' CCATCCTGGCCGCCTTAGCG 3' \\
\hline & $5^{\prime}$ TTGGTCCCTCGGCGCTTCCT $3^{\prime}$ \\
\hline BMP-4 & $5^{\prime}$ ATCCGAGCTGAGGGACGCGA $3^{\prime}$ \\
\hline & 5' CAGCAGTGCGTTGCTCGGGA $3^{\prime}$ \\
\hline 18S RNA & $5^{\prime}$ TCCTGCACCACCAACTGCTTAG $3^{\prime}$ \\
\hline & $5^{\prime}$ AGTGGCAGTGATGGCATGGACT $3^{\prime}$ \\
\hline
\end{tabular}

TEL, Telomere length; $H B G$, human $\beta$-globin; $\alpha$-SMA, $\alpha$-smooth muscle actin; $A L P$, alkaline phosphatase; $V C A M$ - 1 , vascular cell adhesion molecule-1; ICAM-1, intracellular adhesion molecule-1; IL, interleukin; $M C P$, chemoattractant protein; $T N F-\alpha$, tumor necrosis factor- $\alpha$; $C T G F$, connective tissue growth factor; $M M P$, matrix metalloproteinase; $T I M P$, tissue inhibitors of metalloproteinase; $M G P$, matrix Gla protein; $B M P-4$, bone morphogenetic protein-4. 